Вісник Дніпропетровського університету. Біологія. Медицина. - 2012. - Вип. 3, т. 2. - С. 9-14.

Visnyk of Dnipropetrovsk University. Biology. Medicine. - 2012. - Vol. 3, N 2. - P. 9-14.

УДК 581.2+632.15

В. С. Більчук, Г. С. Россихіна-Галича

Дніпропетровський національний університет ім. Олеся Гончара

\title{
АСКОРБАТ-ГЛУТАТІОНОВА СИСТЕМА ЗАХИСТУ РОСЛИН КУКУРУДЗИ В УМОВАХ ДІЇ ІОНІВ НІКЕЛЮ
}

Досліджено вплив іонів нікелю на ростову реакцію проростків кукурудзи гібриду Оржиця 237МВ та вміст низькомолекулярних антиоксидантів в асиміляційних органах. Встановлено залежність морфометричних показників коренів і пагонів проростків від концентрації іонів нікелю. Значне пригнічення росту та розвитку вегетативних органів на стадії ювенільного періоду відбувасться за тривалої дії металу в концентрації 0,05-1,00 ммоль/л. У фотосинтезувальній тканині листків проростків кукурудзи за дії іонів нікелю зафіксовано зміни вмісту відновленого глутатіону та аскорбінової кислоти, що викликають варіювання редукувальної активності тканин. Даний факт може свідчити про наявність окислювального стресу за дії нікелю та участі низькомолекулярних антиоксидантів у процесі адаптації рослин до дії ксенобіотика. Термін відновлення метаболізму аскорбінової кислоти та глутатіону в дослідних зразках визначався концентрацією нітрату нікелю.

\section{В. С. Бильчук, А. С. Россихина-Галычая}

Днепропетровский национальный университет им. Олеся Гончара

\section{АСКОРБАТ-ГЛУТАТИОНОВАЯ СИСТЕМА ЗАЩИТЫ РАСТЕНИЙ КУКУРУЗЫ В УСЛОВИЯХ ДЕЙСТВИЯ ИОНОВ НИКЕЛЯ}

Исследовано влияние ионов никеля на ростовую реакцию проростков кукурузы гибрида Оржица 237МВ и содержание низкомолекулярных антиоксидантов в ассимиляционных органах. Установлена зависимость морфометрических показателей корней и побегов проростков от концентрации ионов никеля. Значительное угнетение роста и развития вегетативных органов на стадии ювенильного периода происходит при продолжительном действии металла в концентрации 0,05-1,00 ммоль/л. В фотосинтезирующей ткани листьев проростков кукурузы при действии ионов никеля зафиксировано изменение содержания восстановленного глутатиона и аскорбиновой кислоты, которые ведут к варьированию редуцирующей активности тканей. Данный факт может свидетельствовать о наличии окислительного стресса при действии никеля и участии низкомолекулярных антиоксидантов в процессе адаптации растений к действию ксенобиотиков. Срок восстановления метаболизма аскорбиновой кислоты и глутатиона в опытных образцах определялся концентрацией нитрата никеля.

\author{
V. S. Bil'chuk, A. S. Rossikhina-Galychaja \\ Oles Honchar Dnipropetrovsk National University
}

\section{ASCORBATE-GLUTATHIONE PROTECTIVE SYSTEM OF MAIZE PLANTS UNDER NICKEL IONS ACTION}

Influence of nickel ions on growth reaction in maize seedlings of Orjitza 237MV hybrid and the content of low-molecular antioxidants in assimilation organs are investigated. The dependence of morphometric parameters of seedling roots and sprouts on the concentration of nickel ions is established. Considerable depression of growth and development of vegetative organs at a juvenile period occurs under long-term action of the metal in concentrations of $0.05-1.00 \mathrm{mM} /$. The changes of reduced glutathione and ascorbic acid 
content under nickel ions influence are found in the leaves photosynthesizing tissue of the maize seedlings. It leads to a variation of the reducing activity in the tissues. The given fact can testify to an oxidizing stress under nickel ions effect and to participation of the low-molecular antioxidants in the plants adaptation to xenobiotics influence. Period of renewal of the glutathione and ascorbic acid metabolism in experimental samples was determined by the concentration of the nickel nitrate.

\section{Вступ}

Нікель - один із головних природних токсикантів рослин у зв'язку зі зростаючим антропогенним забрудненням важкими металами (BM) навколишнього середовища. За його дії відбувається пониження транспірації та вмісту води в рослинах [16; 22]; зменшення продихової провідності, розмірів і кількості хлоропластів [8; 9]; пригнічення активності ферментів азотного обміну [17] та активація ферментів системи антиоксидантів $[10 ; 12 ; 14 ; 16 ; 18 ; 22]$. Токсична дія нікелю, як правило, проявляється в інгібуванні росту рослин за рахунок зниження пластичності клітинних оболонок унаслідок їх лігніфікації, порушень у проходженні мітозу та хромосомних аберацій [8; 16; 21; 24].

Одним із неспецифічних механізмів токсичної дії ВМ, які викликають окислювальний стрес, є утворення в клітинах активних форм кисню (АФК). У відповідь на дію стрес-факторів зростає активність антиоксидантних систем захисту: ферментативних і неферментативних, серед яких значну роль відіграють аскорбінова кислота (АК) та глутатіон, які забезпечують захист клітини від вільних радикалів [14; 20; 22; 23$]$.

Аскорбінова кислота - багатофункціональна сполука. Вона бере участь у детоксикації $\mathrm{H}_{2} \mathrm{O}_{2}$ в аскорбат-глутатіоновому циклі, безпосередньо реагує із супероксидними аніон-радикалами, молекулярним синглетним киснем і гідроксильними радикалами, бере участь у регенерації молекул токоферолу [4; 11]. Функціонування аскорбінової кислоти в рослинній клітині пов'язане з глутатіоном, основна функція якого - підтримання пулу відновленої форми аскорбату. Глутатіон бере участь у неферметативній детоксикації супероксидного радикала, $\epsilon$ донором відновлювальних еквівалентів у глутатіон-аскорбатному циклі (цикл Halliwell-Asada) [5; 6; 25]. Ці низькомолекулярні антиоксиданти реагують на порушення гомеостазу за різноманітних впливів шляхом змін їх накопичення. Участь даних компонентів в адаптації рослин до забруднення довкілля важкими металами вивчена недостатньо. Відсутні дані про зміни редукувальної активності в клітинах рослин залежно від тривалості металевого стресу та їх функціонування після зняття антропогенного навантаження.

У зв'язку з цим мета даної роботи - оцінити роль аскорбінової кислоти та глутатіону в адаптації кукурудзи до дії іонів нікелю, встановити особливості виходу рослин з окислювального стресу.

\section{Матеріал і методи досліджень}

Об’єкт дослідження - проростки кукурудзи середньораннього простого модифікованого гібриду Оржиця 237МВ. Насіння кукурудзи вирощували протягом 3 діб у рулонах фільтрувального паперу на дистильованій воді. На четверту добу проростки висаджували у розчини нітрату нікелю $(0,05,0,5,1,0$ та 5,0 мМ), витримували упродовж 1 та 4 діб. Контролем слугували проростки, які вирощували на дистильованій воді. Всі виміри проводили у рослин упродовж 4 діб дії іонів металу. Післядію стресових факторів визначали на п’яту добу після перенесення рослин на дистильовану воду.

Реакцію рослин на дію іонів нікелю оцінювали за зміною морфометричних показників [2], редукувальною активністю, вмістом аскорбінової кислоти та глутатіону 
[7]. Статистичну обробку даних здійснювали за допомогою пакета Statistica 6,0. Розбіжності між вибірками вважали достовірними при $p<0,01$.

\section{Результати та їх обговорення}

Сумарним відображенням усіх первинних фізіологічних порушень і вторинних відхилень $\epsilon$ інтегрувальні зміни важливих фізіологічних функцій рослинного організму: приріст загальної біомаси і ріст як рослин у цілому, так і певних вегетативних органів [3; 17; 19]. Аналіз даних модельних експериментів із впливу окислювального стресу на морфометричні показники свідчить про достовірне пригнічення росту кореня за 24-годинної дії сполук нікелю тільки в концентраціях 1,0 і 5,0 ммоль/л відносно контрольних рослин відповідно в 1,3 і 1,2 раза (табл. 1). За тривалого (до 96 годин) впливу ксенобіотика на проростки кукурудзи відмічали гальмування ростової реакції коренів, про що свідчить зменшення приблизно удвічі їх довжини в дослідних зразках за дії іонів нікелю в інтервалі концентрацій $0,05-5,0$ ммоль/л. Тільки в умовах хронічної дії проявляється токсичний ефект за мінімальної концентрації металу. При знятті дії стрес-фактора після 96-годинної експозиції відновлення метаболізму кореневої системи відбувається повільно і тільки через п'ять діб витримування проростків на дистильованій воді спостерігали відновлення ростових процесів. Але дослідні рослини були неспроможні подолати відставання інтенсивності росту, що проявлялось утричі меншою довжиною коренів порівняно з контролем (табл. 1).

Таблиичя 1

Вплив іонів нікелю на довжину коренів проростків кукурудзи гібриду Оржиця 237МВ

\begin{tabular}{|c|c|c|}
\hline Варіант & Довжина коренів $(M \pm m)$, мм & \% до контролю \\
\hline \multicolumn{3}{|c|}{24 години дії нікелю } \\
\hline Контроль & $118,1 \pm 0,15$ & 100,0 \\
\hline $\mathrm{Ni}\left(\mathrm{NO}_{3}\right)_{2}, 0,05 \mathrm{MM}$ & $115,2 \pm 0,12$ & 97,5 \\
\hline $\mathrm{Ni}\left(\mathrm{NO}_{3}\right)_{2}, 0,5 \mathrm{mM}$ & $117,1 \pm 0,12$ & 99,2 \\
\hline $\mathrm{Ni}\left(\mathrm{NO}_{3}\right)_{2}, 1,0 \mathrm{MM}$ & $93,0 \pm 0,15 *$ & 78,8 \\
\hline $\mathrm{Ni}\left(\mathrm{NO}_{3}\right)_{2}, 5,0 \mathrm{MM}$ & $102,1 \pm 0,12^{*}$ & 86,4 \\
\hline \multicolumn{3}{|c|}{96 годин дії нікелю } \\
\hline Контроль & $211,1 \pm 0,15$ & 100,0 \\
\hline $\mathrm{Ni}\left(\mathrm{NO}_{3}\right)_{2}, 0,05 \mathrm{MM}$ & $133,2 \pm 0,12^{*}$ & 63,0 \\
\hline $\mathrm{Ni}\left(\mathrm{NO}_{3}\right)_{2}, 0,5 \mathrm{MM}$ & $118,0 \pm 0,12 *$ & 55,9 \\
\hline $\mathrm{Ni}\left(\mathrm{NO}_{3}\right)_{2}, 1,0 \mathrm{MM}$ & $115,2 \pm 0,15 *$ & 54,5 \\
\hline $\mathrm{Ni}\left(\mathrm{NO}_{3}\right)_{2}, 5,0 \mathrm{MM}$ & $106,1 \pm 0,12^{*}$ & 50,2 \\
\hline \multicolumn{3}{|c|}{ післядія } \\
\hline Контроль & $350,3 \pm 0,15$ & 100,0 \\
\hline $\mathrm{Ni}\left(\mathrm{NO}_{3}\right)_{2}, 0,05 \mathrm{MM}$ & $137,0 \pm 0,12^{*}$ & 39,1 \\
\hline $\mathrm{Ni}\left(\mathrm{NO}_{3}\right)_{2}, 0,5 \mathrm{mM}$ & $123,2 \pm 0,12^{*}$ & 35,1 \\
\hline $\mathrm{Ni}\left(\mathrm{NO}_{3}\right)_{2}, 1,0 \mathrm{MM}$ & $118,0 \pm 0,15^{*}$ & 33,7 \\
\hline $\mathrm{Ni}\left(\mathrm{NO}_{3}\right)_{2}, 5,0 \mathrm{MM}$ & $107,1 \pm 0,12^{*}$ & 30,6 \\
\hline
\end{tabular}

Примітка: вірогідні відмінності порівняно з контролем $(p<0,01)$.

Аналіз результатів приросту довжини листків вказує, що на початкових етапах металевого стресу не зафіксовано достовірних змін даного параметра, що узгоджується 3 літературними даними про накопичення та зв'язування нікелю в кореневій системі [8-10]. Але в клітинах вегетативних органів відбуваються метаболічні перебудови, що у першу чергу стосуються окисно-відновної системи.

Вихідний рівень глутатіону у вегетативних органах проростків становив 35,0 мг/100 г наважки. На початковому етапі стресової дії нікелю до 24 годин відмічене 
зменшення вмісту трипептиду (очевидно, за рахунок його участі у процесах знешкодження АФК). Максимальне зниження вмісту глутатіону приблизно удвічі зафіксоване за дії іонів нікелю в концентрації 1,0 і 5,0 мМ. Аналогічні результати отримані в дослідженнях Y. О. Kim [13]: стрес, викликаний дією $C d$, знижував концентрацію глутатіону у клітинах моркви.

За тривалої стресової дії іонів $\mathrm{Ni}$ до 96 годин у листках спостерігали збільшення вмісту антиоксиданта як у контрольних (на 14 \%), так і дослідних зразках (68-80 \%) залежно від концентрації металу (рис. 1), що може бути пов'язано з підвищенням синтезу трипептиду.

У вегетативних органах проростків після зняття дії стресу та перенесення рослин на дистильовану воду впродовж 5 діб зміни метаболізму визначались концентрацією сполук нікелю. У зразках, які перебували під дією 0,05-1,0 мМ токсиканта, метаболізм глутатіону відновлювався, а за 5,0 мМ спостерігали зниження на 56 \% рівня трипептиду відносно контролю.

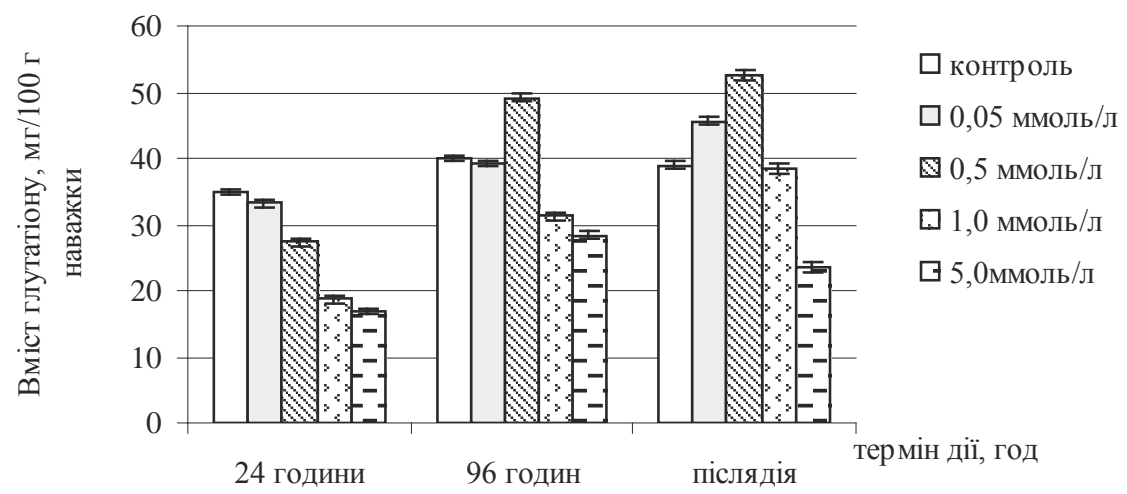

Рис. 1. Вміст глутатіону (мг/100 г наважки) у вегетативних органах проростків кукурудзи за дії іонів нікелю різної концентрації

Листки кукурудзи характеризувались середнім вмістом аскорбінової кислоти (16,4 мг/100 г наважки). За короткочасного металевого стресу достовірних змін концентрації аскорбату не спостерігали. Тривала дія іонів нікелю викликала підвищення вмісту АК в 1,2-1,5 раза при концентрації токсиканта 0,05-1,0 мМ. У варіанті дії максимальної концентрації металу 5,0 мМ вміст аскорбату був достовірно нижчим (в 1,3 раза) відносно контрольних рослин. Дослідження окисновідновних процесів проростків у період післядії стресового фактора показали, що рослини відновили вміст аскорбінової кислоти до рівня контролю.

Виявлений у наших дослідженнях рівень аскорбінової кислоти за порядком збігається з показниками, установленими для сіянців деревних і проростків декоративних квіткових рослин [1]. У листках бирючини звичайної та арктотису гібридного, толерантних до дії хрому, заліза, цинку, марганцю, відмічено вищий вміст аскорбінової кислоти та відновленого глутатіону.

Зміна концентрації аскорбінової кислоти корелювала із загальною редукувальною активністю вегетативних органів проростків. Як свідчать одержані дані, редукувальна активність у стресових умовах збільшувалась 310 до 30 \% відносно контролю. Таким чином, показник накопичення аскорбінової кислоти та глутатіону може бути маркером окисного стресу та стійкості рослинних організмів до дії важких металів. 


\section{Висновки}

Процес адаптації рослин кукурудзи до токсичної дії іонів нікелю відбувався за участі низькомолекулярних антиоксидантів (глутатіону та аскорбінової кислоти), про що свідчать зміни вмісту цих сполук і редукувальної активності за стресових умов. Токсичність дії металу підтверджено змінами морфологічних показників і станом виходу рослин з окислювального стресу. За сумою показників виявлено концентрацію нікелю $(5,0 \mathrm{MM})$, за якої відбуваються значні відхилення гомеостазу проростків кукурудзи.

\section{Бібліографічні посилання}

1. Бессонова В. П. Влияние тяжелых металлов на фотосинтез растений. - Д. : ДГАУ, 2006. $208 \mathrm{c}$.

2. Голубер В. Н. К методике эколого-биологических исследований редких и исчезающих растений в естественных растительных сообществах // Бюллетень государственного Никитского ботанического сада. - 1982. - Вып. 47. - С. 11-16.

3. Гуральчук Ж. 3. Механизмы устойчивости растений к тяжелым металлам // Физиология и биохимия культурных растений. - 1994. - Т. 26, № 2. - С. 107-118.

4. Демура Т. А. Функціонування аскорбатзалежної ланки антиоксидантного захисту проростків кукурудзи за сумісної дії іонів кадмію та нікелю / Т. А. Демура, В. М. Гришко // Фізіологія рослин: проблеми та перспективи розвитку. - У 2 т. - К. : Логос, 1999. - Т. 2. - С. 255-262.

5. Кулинский В. И. Биологическая роль глутатиона / В. И. Кулинский, Л. С. Колесниченко // Успехи современной биологии. - 1990. - Т. 110, вып. 1 (4). - С. 20-33.

6. Митева Л. П.-Е. Изменение пула глутатиона и некоторых ферментов его метаболизма в листьях и корнях растений гороха, обработанных гербицидом глифосатом / Л. П.-Е. Митева, С. В. Иванов, В. С. Алексиева // Физиология растений. - 2010. - Т. 57, № 1. - С. 139-145.

7. Плешков Б. П. Практикум по биохимии растений. - М. : Колос, 1968. - 183 с.

8. Серегин И. В. Токсическое действие и распределение никеля в корнях кукурузы / И. В. Серегин, А. Д. Кожевникова, Е. М. Казюмина // Физиология растений. - 2003. - Т. 50, № 3. С. 793-800.

9. Серегин И. В. Физиологическая роль никеля и его токсическое действие на высшие растения / И. В. Серегин, А. Д. Кожевникова // Физиология растений. - 2006. - Т. 53, № 4. - С. 285-308.

10. Серегин И. В. Роль тканей корня и побега в транспорте и накоплении кадмия, свинца, никеля и стронция / И. В. Серегин, А. Д. Кожевникова // Физиология растений. - 2008. - Т. 55, № 1. C. 3-26.

11. Чупахина Г. Н. Система аскорбиновой кислоты растений. - Калининград : Калинингр. ун-т, 1997. $-120 \mathrm{c}$.

12. Antioxidant capacity of sage grown on heavy metal-polluted soil / I. Stancheva, M. Geneva, M. Hristozkova et al. // Физиология растений. - 2010. - Т. 57, № 6. - С. 857-863.

13. Characterization of cadmium-tolerant carrot cells in response to cadmium stress / Y. O. Kim, T. Fomiko, H. Masakazu, K. Tom // Soil Sci. and Plant Nutr. - 2000. - Vol. 46, N 4. - P. 807-814.

14. Das P. K. Nickel nutrition of plants: Effect of nickel on some oxidase activities during rice (Oryza sativa L.) seed germination / P. K. Das, M. Kar, D. Mishra // Z. Pflanzen-Physiol. - 1978. - Bd. 90. S. 225-233.

15. Effect of heavy metals on nitrate and protein metabolism in sugar beet / S. Kevresan, N. Petrovic, M. Popovic, J. Kandrac // Biol. Plant. - 1998. - Vol. 41. - P. 235-240.

16. Effects of the herbicide MCPA, and the heavy metals, cadmium and nickel on the lipid composition, $\mathrm{Mg}^{2+}$-ATPase activity and fluidity of plasma membranes from rice, Oryza sativa (cv. Bahia) shoots / R. Ros, D. T. Coke, R. S. Burden, C. S. James // J. Exp. Bot. - 1990. - Vol. 41. - P. 457-462.

17. Ernst W. H. O. Effects of heavy metals in plants at the cellular and organismic level / W. H. O. Ernst, G. Shuurmann, B. Markert // Ecotoxycology. Ecological fundamentals. Chemical exposure and biological effect. - Heidelberg : Wiley, 1998. - P. 587-620. 
18. Jaeschke H. Antioxidant defense mechanisms // Comprehensive Toxicology. - 2010. - Vol. 9. P. 319-337.

19. Khalid B. Y. Some effects of nickel toxicity on ryegrass / B. Y. Khalid, J. Tinsley // Plant Soil. 1980. - Vol. 55. - P. 139-143.

20. Redox regulation of the glutathione reductase/iso-glutaredoxin system in germinating pea seed exposed to cadmium / M. Smiri, A. Chaoui, N. Rouhier et al. // Plant Science. - 2011. - Vol. 180. P. 169-181.

21. Rubio M. I. Cadmium and nickel accumulation in rice plants. Effects on mineral nutrition and possible interactions of abscisic and gibberellic acids / M. I. Rubio, I. Escrig, C. Martinez-Cortina // Plant Growth Regul. - 1994. - Vol. 14. - P. 151-157.

22. Schickler H. Response of antioxidative enzymes to nickel and cadmium stress in hyperaccumulator plants of genus Alyssum / H. Schickler, H. Caspi // Physiol. Plant. - 1999. - Vol. 105. - P. 39-44.

23. Sing Gill S. Reactive oxygen species and antioxidant machinery in abiotic stress tolerance in crop plants / S. Sing Gill, N. Tuteja // Plant Physiology and Biochemistry. - 2010. - Vol. 48. - P. 909-930.

24. Stresty T. V. S. Rao ultrastructural alterations in response to zinc and nickel stress in the root cekks of Pigeonpea / T. V. S. Stresty, K. V. Madhava // Environ. Exp. Bot. - 1999. - Vol. 41. - P. 3-13.

25. Strohm M. Regulation of glutathione synthesis in leaves of transgenic poplar (Populus tremula $\mathrm{x}$ P. alba) overexpressing glutathione-synthetase / M. Strohm, L. Jouanin, K. J. Kunert // The Plant J. 1995. - Vol. 7, N 1. - P. 414-145.

Надійшла до редколегії 18.06.2012 